\title{
Criminal Law, Evidence and Procedure
}

\author{
Tatyana Eatwell
}

Christopher Sargeant

\section{Introduction}

As in the previous legal year ${ }^{1}$ 2011-12 has seen two themes dominate the criminal jurisprudence of the Supreme Court. Most importantly, in Ambrose v Harris ${ }^{2} H M$ Advocate $v P^{3} M c G o w a n v B^{4}$ and Jude v HM Advocate $5^{5}$ the Supreme Court has been called upon to clarify various aspects of its controversial recent decision in Cadder v HM Advocate ${ }^{6}$ Secondly, in $R v$ Gnango 7 it has been required to elucidate the law on joint enterprise responsibility and, at least implicitly, to confront the age-old question of how far public policy arguments should overtake the need for strict legal rules when determining an appropriate legal response in this area.

\section{Explaining Cadder}

In the 2010 case of Cadder, the Supreme Court unanimously followed the approach of the European Court of Human Rights in Salduz v Turkey ${ }^{8}$ and held that, absent compelling reasons, denying an accused person access to a solicitor whilst he was detained by the police violated his rights under Articles 6(1) and

\footnotetext{
See Z Prodromou \& S Wilson, 'Criminal evidence and procedure' (2012) 1(2) CJICL 66.

2 [2011] UKSC 43. The full title of the case is Ambrose v Harris; HM Advocate v G; HM Advocate v $M$.

3 [2011] UKSC 44.

4 [2011] UKSC 54.

5 [2011] UKSC 55. The full title of the case is Jude v HM Advocate; Hodgson v HM Advocate; Birnie v HM Advocate.

6 [2010] UKSC 43.

7 [2011] UKSC 59.

8 (2009) 49 EHRR 19.
} 
6(3)(c) of the European Convention on Human Rights (ECHR) $]^{9}$ In doing so, the Supreme Court overruled a series of recent unanimous decisions of the Scottish High Court of Justiciary (particularly Paton v Ritchie ${ }^{10}$ Dickson v HM Advocat ${ }^{11}$ and HM Advocate $v$ McLear ${ }^{12}$; rendered at least thirty years of past practice unlawful ${ }^{13}$ and caused a serious diplomatic rift between itself and the Scottish Government 14

Notwithstanding that this decision directly resulted in over one thousand cases being dropped ${ }^{15}$ and drew an immediate legislative response from the Scottish Parliament ${ }^{16}$ Cadder in fact left various questions as to its ambit unanswered. A selection of these issues have since visited the Supreme Court for clarification in the last judicial year. In its responses, the Supreme Court has arguably limited the remit of Cadder in both physical and temporal scope, and likely reined back its future impact.

\subsection{Adverse admissions obtained prior to arrival at an authorised detention centre}

The first clarification sought from the Supreme Court concerned whether the rule in Cadder applied to adverse admissions obtained during police interrogation, but prior to the arrival of a suspect at an authorised detention facility. In Ambrose, a four to one majority of the Supreme Court (Lord Kerr dissenting) held that it did not. In the view of the Court, the rule only applied to interrogations conducted in a formal custodial institution. In $M$ therefore, where the suspect was questioned at his own home as a witness (before his involvement as an offender was suspected) the rule in Cadder did not automatically prevent reliance upon his admissions. The matter was accordingly remitted to the High Court of Justiciary.

A more complicated situation arose in $G$, a case in which the appellant was questioned in his flat whilst handcuffed (seemingly after having been arrested for another offence). Here, the Supreme Court held (rightly, it is submitted,

9 Convention for the Protection of Human Rights and Fundamental Freedoms, 4 November 1950, 213 UNTS 221.

2000 SLT 239.

2001 SLT 674.

2010 SLT 73.

See e.g. Cadder, above n 6, para 4 (Lord Hope).

See Prodromou \& Wilson, above n 1, 67 for general discussion.

R White \& P Ferguson, 'Sins of the father? The "sons of Cadder"', (2012) 5 Crim LR 357, 357.

16 Criminal Procedure (Legal Assistance, Detention and Appeals) (Scotland) Act 2010. 
since the only factual difference was physical location) that this was akin to being in custody. In the view of Lord Hope, the act of handcuffing represented a 'significant curtailment of his freedom of action' ${ }^{17}$ The rule in Cadder was therefore engaged.

\subsection{Adverse admissions obtained after the right to legal advice has been waived}

The second clarification sought concerned whether the rule in Cadder applied where an accused was in fact offered legal advice, but waived that right without taking separate legal advice as to whether to do so. In McGowan, the Supreme Court once more held that it did not (Lord Kerr again dissenting in part) ${ }^{18}$ At the same time however, the majority noted that any waiver must be 'voluntary, informed and unequivocal 19 They added that the test for this would be particularly stringent where the accused was considered vulnerable 20

The interpretation of this ruling was shortly thereafter considered in Birnie, a case in which the accused was eighteen years old and had just been informed that he was to be detained for the weekend. In such circumstances, Lord Kerr thought it inescapable that his decision to [waive his right to counsel] could not in any circumstance be regarded as an effective waiver of his right 21

\subsection{Evidence obtained as a result of adverse admissions-the fruit of the poisoned tree?}

The third and final clarification sought from the Supreme Court concerned whether evidence obtained as a result of adverse admissions from interrogations which violated the rule in Cadder should itself be automatically excluded under the 'fruit of the poisoned tree' rule. In $P$, the Supreme Court held that this was a matter upon which neither Salduz nor Strasbourg jurisprudence more generally provided guidance; indeed the Strasbourg Court had purposefully declined to do so 22 Accordingly, the Supreme Court could again only remit the matter to the High Court of Justiciary.

\footnotetext{
See $G$, above n 2, para 45 (Lord Hope discussing Zaichenko v Russia [2010] ECHR 185, para 48).

18 Cf above n 5, para 32 (Lord Justice-Clerk Gill).

19 See McGowan, above n 4, para 17 (Lord Hope, approving Millar v Dickson [2001] UKPC D4, para 31 (Lord Bingham)).

20 Ibid, para 35 (Lord Hope).

${ }^{21}$ Above n 5, para 56 (Lord Kerr).

22 See e.g. Gäfgen v Germany (2011) 52 EHRR 1, para 162
} 


\subsection{Overarching trends-conciliation, deference and the rise of constitutionalism}

Three overarching trends can be discerned from these decisions. The first is the more conciliatory tone adopted by the Supreme Court in its approach to Scottish criminal law. In part, this is achieved by clear and continuous restatement of its own jurisdiction. In Ambrose for example, Lord Hope was quick to note that the role of the Supreme Court was limited to engaging in a 'consideration of the devolution issue which is raised' 23 The High Court of Justiciary, by contrast, remained the court of last resort in all criminal matters in Scotland24 This contrasts with the view expressed by First Minister Alex Salmond in the wake of Cadder that the Supreme Court was interfering in Scottish criminal law 25 jurisdiction denied to it by the Act of Union 26

Nonetheless, the Supreme Court has also gone beyond merely clarifying its own procedural role and has narrowed the application of the rule in Cadder as a matter of substance. Although its basic premises now extend geographically to custody both de jure and de facto, it has not been given universal application to any interaction with the police. Further, the right can be waived without the need for separate legal advice and evidence obtained from any unlawful admissions is not itself automatically excluded, rulings which are clearly open to future abuse.

It is likely, then, that Cadder will have a much more limited future impact than might previously have been thought. As Ferguson and White have noted, the current position allows for 'a restoration to as close to the pre-Cadder position as is now possible, if the High Court chooses to so decide $\sqrt{27}$ Given that the result in Cadder was opposed by the Scottish Government, Parliament and judges (who had themselves refused both the initial application and the original attempt to appeal the decision to the Supreme Court), an opportunity to limit its scope is one they can be expected to take without disappointment.

The second overarching trend is the continuing restrictive approach of the Supreme Court to judgments of the European Court of Human Rights. In this regard, the Human Rights Act 1998 does not bind domestic courts to apply judgments of the Strasbourg Court per se, only requiring that they are taken

\footnotetext{
Above n 2, para 14 (Lord Hope).

24 Ibid.

25 See e.g. R Dinwoodie, 'Salmond: Scotland's legal system is being undermined' The Herald (Scotland), 27 October $2010<$ http://www.heraldscotland.com/news/crime-courts/salmondscotlands-legal-system-is-being-undermined-1.1064085> [accessed 10 December 2012].

26 Act of Union 1707 Article 19.

27 White \& Ferguson, above n 15, 365.
} 
into account ${ }^{28}$ In interpreting this rule, however, judicial practice has been heavily influenced by the 'mirror principle' set out by Lord Bingham in $R v$ Special Adjudicator ex parte Ullah ${ }^{29}$ In particular, Lord Bingham thought that the duty upon domestic courts was 'to keep pace with the Strasbourg jurisprudence as it evolves over time: no more, but certainly no less 30

Increasingly, however, this rule has been understood as also including a converse duty to do 'no less, but certainly no more ${ }^{31}$ In Ambrose, for example, Lord Hope argued that it was 'not for this court to expand the scope of the Convention right further than the jurisprudence of the Strasbourg court justifies $\sqrt[32]{2}$ Lord Kerr, by contrast, (albeit in a lone dissent) argued that:

[I]t is not open to courts of this country to adopt an attitude of agnosticism and refrain from recognising such a right simply because Strasbourg has not spoken [...] It is therefore the duty of this and every court [...] to resolve the question of whether a claim to a Convention right is viable or not, even where the jurisprudence of the Strasbourg court does not disclose a clear current view 33

The third trend, underpinned by the issues outlined above, is the ongoing evolution of the Supreme Court into a UK Constitutional Court. This change has been driven by the increasing numbers of cases calling upon the Supreme Court to exercise a form of constitutional review, either de jure over laws from devolved institutions, or de facto over Acts of the UK Parliament. At least at a prima facie level, the Supreme Court is increasingly challenging many of the established assumptions of the UK constitutional arrangement and gradually rewriting its place within it.

That this evolution is occurring can be seen from the ever increasing number of cases raising issues surrounding the compatibility of domestic law with the ECHR and EU law ${ }^{34}$ and with the division of powers under the devolution settlements 35 Also of particular note are the recent decisions in $R$ (Jackson)

\footnotetext{
28 Human Rights Act 1998 s 2.

29 [2004] UKHL 26.

30 Ibid, para 20 (Lord Bingham); see also Cadder, above n 6, para 51 (Lord Hope).

31 See e.g. R (Al-Skeini) v Secretary of State for Defence [2007] UKHL 26, para 106 (Lord Brown).

32 Ambrose, above n 2, para 20 (Lord Hope).

33 Ibid, paras 128-130.

$34 R v$ Secretary of State for Transport; ex parte Factortame Ltd (No 2) [1991] 1 AC 603.

35 Re Local Government Byelaws (Wales) Bill 2012 [2012] UKSC 53.
} 
$v$ Attorney Genera ${ }^{36}$ and AXA General Insurance Ltd $v$ HM Advocate ${ }^{37}$ on the relationship between Acts of Parliament (both at the UK and devolved levels) and common law. These decisions may well form the basis of a direct challenge to sovereignty of Parliament in the future, but for now at least show the ongoing empowerment of the Supreme Court in opposition to the other institutions of State.

Although it is beyond the scope of this work to consider this transformation of the UK constitutional system in any detail, this is a development worthy of particular note. This is especially so given predictions by many commentators and even some judges that the replacement of the judicial function of the House of Lords with a Supreme Court would have little practical effect ${ }^{38}$ Although this shift has been happening for some time, it is clearly one which has been enhanced (at least implicitly) by the physical move of the Court across Parliament Square to the Guildhall.

\section{Joint enterprise-policy at the expense of legal clarity?}

Joint enterprise has been a source of concern in recent years, particularly when used in the prosecution of murder ${ }^{39}$ Attempts by the courts to define the scope of joint enterprise have come under criticism for allowing public policy to become too intertwined with the legal principle 40 It has been argued that the dominance of policy considerations, particularly directed towards deterring gang-related violence, has led to an overly complex catch-all doctrine that can

36 [2005] UKHL 56.

37 [2011] UKSC 46.

38 See e.g. D Neuberger, "The Supreme Court: is the House of Lords "losing part of itself"?, The Young Legal Group of the British Friends of the Hebrew University Lecture, 2 December 2009 <http://www.judiciary.gov.uk/Resources/JCO/Documents/Speeches/mr-supremecourt-lecture-dec-2009.pdf> [accessed 10 January 2013].

39 See further 'Justice Committee Joint Enterprise Inquiry, written evidence submitted: written evidence submitted by Tim Moloney QC and Simon Natas to the Home Affairs Select Committee on Joint Enterprise', September $2011<$ http://www.publications.parliam ent.uk/pa/cm201012/cmselect/cmjust/writev/jointent/jointent.pdf> [accessed 8 November 2012].

40 A Davies, 'Case preview: $R v$ Gnango', UKSC blog, 25 July $2011<$ http://ukscblog.com/casepreview-r-v-gnango> [accessed 2 December 2012]. 
lead to injustice 41

In the case of Gnango ${ }^{42}$ the Supreme Court was presented with an opportunity to clarify the law, albeit in the context of an unusual set of circumstances concerning a gunfight between two people. The decision was timely. The judgment was handed down just six weeks after the Home Office Justice Committee on Joint Enterprise heard oral evidence in an inquiry into the issues arising out of the doctrine. However, those hoping that the Supreme Court might 'delve deeper into the principles on joint enterprise that the extreme facts of the case demand ${ }^{43}$ and revisit examination of the scope of the doctrine as a whole will sadly be disappointed.

Considerations of public policy have long stood at the heart of joint enterprise rules. As Sir Robin Cooke said in Chan Wing-Siu v R:

What public policy requires was rightly identified in the submissions for the Crown. Where a man lends himself to a criminal enterprise knowing that potentially murderous weapons are to be carried, and in the event they are in fact used by his partner with an intent sufficient for murder, he should not escape the consequences by reliance upon a nuance of prior assessment, only too likely to have been optimistic 44

It is evident from the judgment in Gnango that policy lay behind the lines of reasoning mooted in support of the restoration of the conviction of the intended victim of a fatal gunshot. As Lord Brown said, "[t]he general public would in my opinion be astonished and appalled if in those circumstances the law attached liability for the death only to the gunman who actually fired the fatal shot 45 Contrary to this observation, the authors have found no evidence of public outrage following the Court of Appeal's decision to quash the conviction 46

41 Moloney \& Natas, above n 39; M George, 'Long on policy, short on principle', The Justice Gap <http://thejusticegap.com/2011/12/long-on-policy-short-on-principle/> [accessed 2 December 2012]; A Davies, 'A more American legal model for gang violence?' The Guardian, 25 July 2011. <http://www.guardian.co.uk/law/2011/jul/25/joint-enterprise-supreme-courtgnango? INTCMP=SRCH $>$ [accessed 2 December 2012].

42 Gnango, above $\mathrm{n} 7$.

43 D Ormerod, 'Joint enterprise: murder-killing of bystander by other party in gunfight' [2011] Crim LR 151, 158.

44 [1985] AC 168, 177.

45 Gnango, above n 7, para 68 (Lord Brown).

46 R Gnango [2010] EWCA Crim 1691. 
Further, it ought to be remembered that had the Supreme Court found in favour of Gnango, he would not have got away scot-free. He had also been convicted of attempted murder and possession of a firearm with intent to endanger life, receiving a sentence of imprisonment of at least fifteen years.

Given the facts of the case, the concern with policy is understandable. Gnango, a 17-year-old boy, had been in a shoot-out with another, referred to as 'Bandana Man' $(B){ }^{47}$ During the course of the shoot-out, a passer-by, Ms Pniewska, was killed by a stray bullet. The facts are horrendous. Nevertheless it is important to note that it was not in dispute that $\mathrm{B}$ was the first to fire and that $B$ had fired the lethal shot. Had he been prosecuted, all were agreed that he would have been found guilty of murder by reason of transferred malice. The elephant in the room is the fact that to date B has not been prosecuted. It is submitted that in B's absence, the securing of a conviction for Ms Pniewska's murder has been at the cost of legal precision.

The facts of the case are straightforward, but the reasoning of the Supreme Court is convoluted and does little to clarify the law. This is explored further in this volume by Findlay Stark in "A most difficult case": on the ratio of Gnango. As Lord Kerr said in his dissenting judgment, "[v]arious bases on which Gnango might-or should-be found guilty of the murder of Ms Pniewska have been canvassed in the course of argument and in the judgments of other members of the court 48 The majority agreed that Gnango's murder conviction should be restored, but were divided on the reasoning as to why ${ }^{49}$ With unanimity, the Supreme Court agreed with the Court of Appeal that the jury could not properly have convicted on the basis of 'parasitic accessory liability'-whether, having agreed to commit an affray and in the course of committing the affray, B went beyond what was agreed, by causing serious injury with intent, and Gnango foresaw that risk that B would do so. Despite observing that it would be 'undesirable [...] if a practice developed of relying on the doctrine of parasitic accessory liability to charge with murder parties to an affray who had not themselves intended that it would result in serious injury $\sqrt[50]{50}$ the Supreme Court did so without clarifying the scope of this principle, leaving the waters ever muddied. As Ormerod has observed, 'this has serious implications, and it is

\footnotetext{
47 Gnango, above $\mathrm{n} 7$, para 7. The man was described as wearing a red bandana that covered his face.

48 Ibid, para 110 (Lord Kerr).

49 This did not worry Lords Phillips and Judge who felt that the differences were not substantial. See para 62.

50 Gnango, above n 7, para 41 (Lords Phillips and Judge).
} 
unclear why it is limited to affray

Further evidence of policy overshadowing legal precision lies in the fact that the jury was directed to consider only parasitic accessory liability and not some other form of secondary liability. The issue of whether or not Gnango encouraged or aided and abetted B to shoot at him and intended to do so was not left to the jury. This approach, rejected by the trial judge, was advocated in the leading judgment of Lords Phillips and Judge (Lords Wilson and Dyson agreeing). It is questionable, however, whether the Supreme Court could determine that Gnango was properly convicted on that basis. As Lord Kerr said in his dissenting judgment:

In the absence of a specific direction on Gnango's intention to encourage B to shoot at him, I do not consider that the verdict of the jury can be upheld on the basis that it was founded on their conclusion that he either had the requisite intention or that the virtually certain result of his firing at $\mathrm{B}$ was that he would return fire and that Gnango knew that this was virtually certain to occur 52

It is regrettable that Gnango did not gainsay the conclusions of the Justice Committee's inquiry that ' $t$ ] he lack of clarity over the common law doctrine on joint enterprise is unacceptable for such an important aspect of the criminal law $\sqrt[53]{5}$ Gnango may have achieved a certain kind of justice for the tragic death of Ms Pniewska, but there remains generally a growing sense that the application of the law generally has led to injustice 54

Attempts to define the scope of joint enterprise have undoubtedly caused a great deal of confusion and contributed to the increasing complexity of the doctrine ${ }^{55}$ In practice, joint enterprise is deployed to cover a variety of different acts committed by secondary parties, from encouragement through presence 56 to direct participation in the fatal act. As such, even in cases of spontaneous violence, the scope of joint enterprise 'can be drawn so wide that those who would appear

51 D Ormerod, 'Worth the wait?' [2012] Crim LR 79, 80.

52 Gnango, above n 7, para 125 (Lord Kerr).

53 House of Commons Justice Committee Report, Joint Enterprise, Eleventh Report of Session 2010-12, 17 January 2012, HC 1597, 18 <http://www.publications.parliament.uk/pa /cm201012/cmselect/cmjust/1597/1597.pdf $>$ [accessed 8 November 2012].

54 See Moloney \& Natas, above $\mathrm{n} 39$.

55 Ibid; see also Ormerod, above n 43.

56 See e.g. $R v$ Stringer [2011] EWCA Crim 1396. 
to have little or no culpability for the killing can be included within it $\sqrt{57}$ As long as the broad scope of joint enterprise continues to be justified on the basis that it is a deterrent to gang-related crime, it is unlikely that Parliament will rise to the challenge of clarifying the law. The previous Lord Chancellor and Secretary of State for Justice, Kenneth Clarke, made the position clear when he said that the government 'remain[s] to be convinced about the need for law reform' on the issue and that he was 'keen to avoid consulting on measures that could weaken the law in this area or undermine the Government's efforts to tackle crimes committed by gangs $\sqrt[58]{58}$ For the foreseeable future, it looks like public policy will continue to override legal clarity in the law of joint enterprise.

\section{Conclusion}

Given the controversy that Cadder and Gnango have caused, the issues raised are likely to be seen again in the Supreme Court in the near future. This is particularly true in respect of Cadder, given that the constitutional arrangement of the United Kingdom and its relationship with the European Court of Human Rights continues to feature prominently in wider legal debate. The full implications of Gnango are also yet to be seen. However, it can be expected that the courts will hear substantial legal argument concerning its application to other, perhaps less unusual, circumstances. Once again, we must wait to see how both cases develop in the coming months. The 2012-13 review is awaited with interest.

57 Moloney \& Natas, above n 39, para 24.

58 K Clarke, 'Joint enterprise: government response to the Committee's Eleventh Report of Session 2010-12-Justice Committee', 13 March 2012, HC 1901, 3 <http://www.publications.parlia ment.uk/pa/cm201012/cmselect/cmjust/1901/1901.pdf.> [accessed 8 November 2012]. 